\title{
Coalition Cooperation Defines Roadmap for E85 and Biodiesel
}

Banners snapped in the breeze and signs announced to customers that E85 had arrived at an established fueling station in Fort Collins, Colorado. This was just one of 40 planned grand openings of E85 fueling facilities across Colorado in 2007-all the result of the efforts of the Colorado Biofuels Coalition, formerly the Colorado E85 Coalition.

The Colorado Biofuels Coalition, a volunteer coalition with 15 voting members, was established in late 2005 by the Governor's Energy Office (GEO). GEO's senior deputy director, Ed Lewis, led the initial build-up of the coalition. As retail prices for unleaded gasoline reached $\$ 3$ a gallon, the state began to study the economics of alternative fuels such as E85, a blend of up to 85 percent ethanol and 15 percent gasoline. At the request of the coalition, the Colorado Department of Revenue counted 300,000 flex-fuel vehicles in the state (later analysis put the number closer to 200,000). But at the beginning of 2006, Colorado had just 10 public E85 fueling stations to serve these ethanol-capable vehicles. "It was impossible to imagine that the drivers of those vehicles would be able to locate a station selling ethanol or whether 10 stations could handle that much demand for E85," Lewis said. Nationally, in 2006, there were an estimated 5 million flex-fuel vehicles on U.S. highways, and less than 1 percent of gasoline stations offered E85.

\section{Coalition Formation}

In early 2006, GEO learned of plans to construct ethanolproducing plants in the state. GEO wanted to continue to attract this construction and did not want the fuel shipped out of state. The office decided it needed to bring together the diverse entities that could work together to increase the availability of E85 in the state.

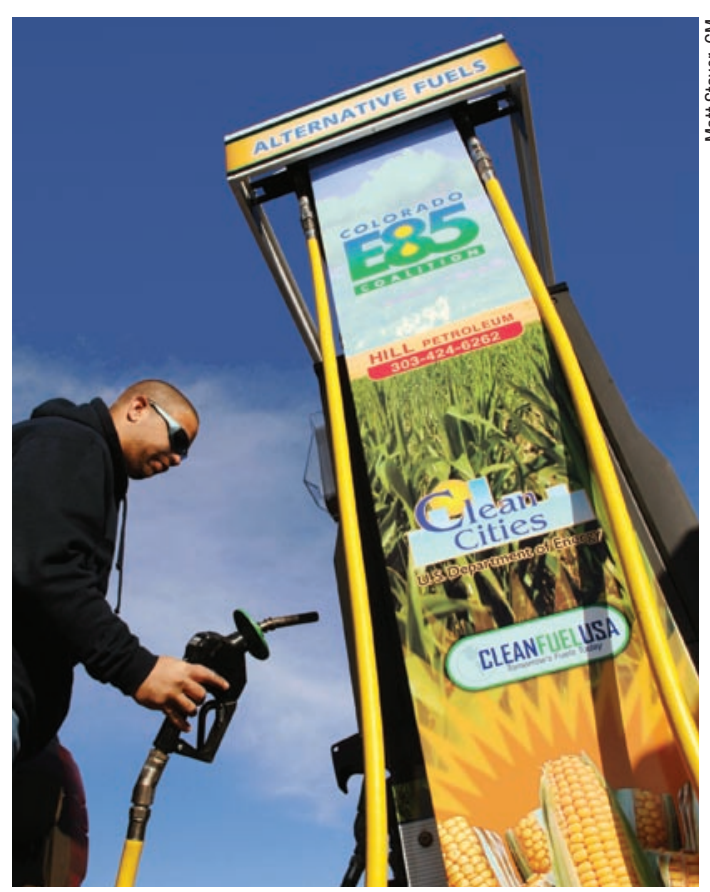

Publicizing the opening of E85 fueling facilities is one of many strategies for promoting alternative fuel and vehicle use.
SEO identified major stakeholders such as ethanol producers; small and large fuel retailers; local, state, and federal government representatives including the Colorado Department of Agriculture, the Colorado Department of Public Health and Environment, and the Regional Air Quality Council; automobile dealerships; fuel distribution and marketing groups; economic development groups; and environmentalists. One representative from each stakeholder group has a vote on the coalition steering committee. GEO also asked major automobile manufacturers to join, and General Motors (GM) answered the call. Colorado became one of 11 states where the auto manufacturer is focusing sales and marketing efforts to promote flex-fuel vehicles. The company not only promotes GM flex-fuel vehicles in the showroom but also supports and publicizes E85 fuel.

In the formation of a coalition, it was important to avoid competitive conflicts that might impede open and candid discussion. Several automobile manufacturers on the same panel might have been reluctant to share information about manufacturing or marketing plans. "You really have to have 100 percent buy-in from each coalition member," Troy Hill, vice-president and general manager of Hill Petroleum, explained. "In my own case, as a small fuel provider, I would not feel I could be open with people in my same category of operation." Hill also pointed out that there needs to be a balance between regulatory and state officials and operational people who are familiar with station infrastructure, construction, and delivery issues.

Other key factors that have helped the coalition work as a team include:

- Specific station and fuel goals developed by the coalition

- Clear and transparent decision-making process 
- Open meetings and published minutes

- Commitment by the coalition to be a non-lobbying group.

\section{Coalition Funding}

The mission of the Biofuels Coalition is to provide funding and partnerships to strategically place many biofuel pumping facilities throughout Colorado. The coalition's original goal was to double the number of E85 pumps from 10 to 20 and double the E85 gallons used in Colorado within 12 months.

Funding for the coalition and its planned support of E85 infrastructure came from several sources. The GEO granted the coalition a budget of $\$ 220,000$ from the State Energy Plan fund to educate station owners about tax credits available for alternative fuel infrastructure. It added another $\$ 330,000$ from Petroleum Violation Escrow funds for grants capped at $\$ 15,000$ per installation of new E85 fueling infrastructure. Two major Colorado fuel distributors-Pester Marketing and Western Convenience-pledged to install at least 22 new E85 fueling sites in the state with the funding. Additionally, Clean Cities coordinators from Denver and Colorado Springs assisted in developing and submitting a grant proposal to the Department of Energy (DOE). This Clean Cities effort resulted in a grant of roughly $\$ 390,000$. This grant was one of many examples of coalition members working together to build a compelling case for infrastructure development in Colorado. To ensure fair and equitable consideration, the coalition developed a decision matrix that capped individual grants for infrastructure at $\$ 15,000$ per station or 35 percent of out-of-pocket costs after tax incentives, whichever was less.

When the Colorado Corn Growers Association joined the coalition in 2006 as a partner, they contributed additional funds from a two-year matching grant from the Congestion Mitigation and Air Quality Improvement Program (CMAQ). The grant, administered by the Regional Air Quality Council, was limited to the seven-county greater Denver metro area to support the construction or conversion of five E85 stations, whether new or retrofitted, with private or public access, according to Katrina Reed, ethanol project manager at Colorado Corn. Through the partnership, the coalition was able to support E85 sites in the seven-county area with CMAQ funds and direct its other funds to fueling sites out of the area. "The current CMAQ grant ends in September 2007, and we plan to apply for another grant," Reed said. "We see opportunities in Yuma and Weld Counties that were not included in the current grant, and we hope to be able to expand E85 into those rural counties."

Dealership training to educate car sales staff about flex-fuel vehicles was also part of the CMAQ grant program. "We designed a dealership kit that includes a seven-minute video on E85, a hang tag for each flex-fuel vehicle, a flexible fuel vehicle purchasing guide, and coupons for free E85 fuel,"

\section{What Is Clean Cities?}

Clean Cities is a government-industry partnership designed to reduce petroleum consumption in the transportation sector by advancing the use of alternative fuels and vehicles, idle reduction technologies, hybrid electric vehicles, fuel blends, and fuel economy.

\section{What Is E85?}

E85 is a blended fuel consisting of anywhere from 70 percent ethanol and 30 percent gasoline in the winter to 85 percent ethanol and 15 percent gasoline in the summer.

\section{What Are Flexible Fuel Vehicles?}

Flexible fuel vehicles, sometimes referred to either as flex-fuel vehicles or FFVs, are specially designed to run on any ethanol fuel blend up to 85 percent ethanol. Equipment in the flex-fuel vehicle reads the fuel blend, automatically making adjustments so drivers can fuel with E85 or switch to gasoline if E85 is not available. An estimated 5 million flex-fuel vehicles are on U.S. highways today. However, many flex-fuel vehicle drivers do not know about their vehicles' alternative fuel capability.

\section{What Is Biodiesel?}

Biodiesel is a renewable fuel produced from agricultural crops, waste vegetable oils, and animal fats. Soybean oil is the preferred biodiesel feedstock in the United States. Biodiesel is typically sold in blends; B2 (2 percent biodiesel), B5 (5 percent biodiesel), and B20 (20 percent biodiesel) are the most prevalent. Most public biodiesel pumps dispense B20.

\section{Coalition Voting Members}

Coalition voting members represent key stakeholders needed to build and support biofuels infrastructure.

- Automobile dealership

- Consumer

- Economic development

- State Office of Health and Environment

- Ethanol producer

- State fleet

- Fuel distributor
- Small retailer

- Large retailer

- State Air Quality

- Agricultural

- Environmental

- Petroleum marketing

- Media and communications

- DOE Clean Cities Program

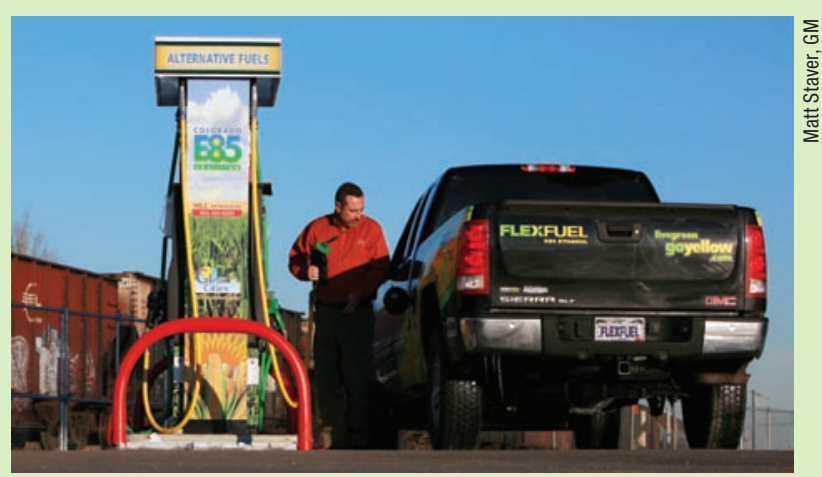

The coalition goal is for 50 Colorado stations to offer E85 by the end of 2007. 
Reed explained. “Sometimes dealer representatives aren't familiar with flex-fuel vehicles. We wanted to give them information that they could pass on to their customers."

On top of the cash grants available to offset out-of-pocket infrastructure costs, the coalition determined that it was imperative that potential infrastructure builders needed to understand and be positioned to receive the various federal and state infrastructure tax credits available. The coalition developed and offered this information.

The federal Energy Policy Act (EPAct) of 2005 (Section 1342) provides a tax credit equal to 30 percent of the cost of alternative refueling property, up to a maximum of $\$ 30,000$. Owners who install qualified refueling infrastructure on multiple sites can use the credit for each property.

Colorado state infrastructure tax credit for tax years before January 1, 2009, equals 35 percent of the actual cost of construction, reconstruction, or acquisition of an alternative fuel refueling facility that is directly attributable to the storage, compression, charging, or dispensing of alternative fuels to motor vehicles. For alternative fuel refueling facilities that are generally accessible for use by the public, the 35 percent will be multiplied by 1.25 . The tax credit has a maximum value of $\$ 400,000$ in any consecutive five-year period for each refueling facility. The tax credit will drop to 20 percent between January 1, 2009, and January 1, 2011.

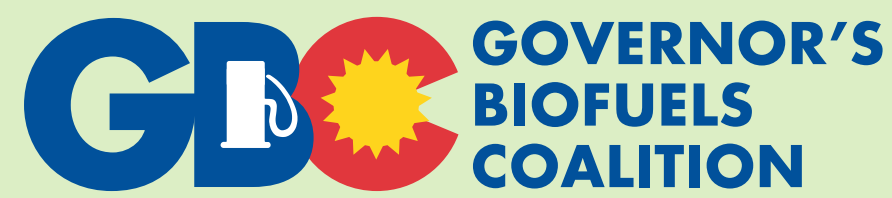

Advancing $E 85$ and Biodiesel in Colorado

\section{How to Get Started}

- Establish a diverse coalition

- Set goals and metrics as a team

- Understand and develop available funding options and incentives

- Develop decision matrix for funding

- Leverage available resources

- Map vehicle and station locations

- Increase awareness through press releases and media events

- Establish relationships with equipment providers

- Establish reliable ethanol and biodiesel supply

- Promote funding availability to retailers and municipalities

- Award funding quickly and make the process easy

- Hold pump openings and media events to fuel momentum

- Celebrate successes.
In Colorado, the combined federal and state tax incentives amount to more than 70 percent of the infrastructure costs in tax credits.

\section{Issues Addressed}

As with all major projects, there have been roadblocks and issues along the way. The coalition decided to target specific geographical locations for E85 dispensers and subsequently developed three initial requirements for a station to be considered for support from the coalition:

- Near a ZIP code with large numbers of flex-fuel vehicles

- Close by or at a busy intersection

- Near a major highway, thoroughfare, toll road, or interstate.

The coalition had a plan to be selective about choosing stations for E85 sites but ended up going with early adopters, those enthusiastic people eager to get the ball rolling. Two marketers in Colorado, Pester Marketing and Western Convenience, jumped on board as major fuel distributors and coalition partners.

Hill Petroleum in Denver opened the first station to offer E85 pumps as part of the coalition's activities. "Our station was already in the process," said Troy Hill, "but we were able to get assistance from the coalition and repay that assistance by sharing what we had learned. We educated ourselves on the issues and were able to help others about what to ask for from suppliers and what to expect from them."

From a business case perspective, station owners needed to see the potential for a consistent demand for the fuel before making the commitment. The coalition identified federal, state, and local government fleets as major potential customers for alternative fuels. Under EPAct of 1992, 75 percent of new covered light-duty vehicles acquired by federal fleets, such as the U.S. Post Office and the Department of Defense, as well as covered state-owned fleets, must be alternative fuel vehicles. Under Sections 701 and 1831 of EPAct of 2005, federal fleets are required to use alternative fuel in their alternative fuel vehicles unless such fuel is not reasonably available to the fleet or is unreasonably more expensive than petroleum fuel.

Many fleets that have flex-fuel vehicles never use E85 or biodiesel because of unavailability. The coalition facilitated communication between station owners and fleets to work out specific issues facing fleets about availability and purchasing mechanisms. Colorado Clean Cities coordinators are following up with local fleets to connect them with alternative fuel station owners and encourage future purchases of biofuel vehicles.

Pricing was another issue faced by the coalition. E85 has a higher octane level than regular or premium gasoline but a lower energy content; therefore, vehicles using E85 travel fewer miles per gallon than when using petroleum-based fuel. To ensure that E85 is cost competitive with gasoline, the 
wholesale price needed to be a minimum of 15 to 20 percent less than gasoline. Unless station owners could be assured that adequate supplies would be available at a price consistent with the energy value of ethanol versus gasoline, there was little incentive for them to join the project. After a few false starts, agreement was reached to secure a reliable source of fuel at a predictable price from a local producer.

Another concern was the issue of tank and pump equipment certification by Underwriters Laboratories (UL). Triggered by the need to establish comprehensive safety requirements for an entire E85 dispenser system, UL in October 2006 suspended its official listings (certification) for individual parts that compose an E85 fuel dispenser. Realizing the implications to developing E85 infrastructure in Colorado, GEO and the coalition facilitated meetings with the Colorado Division of Oil and Public Safety, the Colorado Division of Fire Safety, and the Fire Marshals' Association of Colorado. These meetings resulted in a published guideline for use until UL completes its testing and certification process for equipment dispensing fuels containing more than 15 percent alcohol.

\section{State and Public Partnerships}

In Colorado, the state fleet of 5,700 vehicles includes 520 flexfuel vehicles. Those 5,700 mostly light-duty vehicles use an estimated 4 million gallons of fuel per year. "We needed to get alternative fuel infrastructure off the ground, so we could use it in the vehicles we already have and in the vehicles we are mandated to add to the fleet," said Art Hale, Colorado state fleet manager. The coalition supported strategic partnerships between the state fleet and various municipal and county governments. "The coalition has been able to offer subsidies to local government entities for the installation of E85 fueling sites. The state fleet has then been able to purchase available E85 fuel from these facilities, support the state fleet's economic investment in flex-fuel vehicles, and increase E85 consumption," Hale explained.

\section{Goals and Next Steps}

All sectors of the Biofuels Coalition are working together to overcome market barriers and raise awareness of flex-fuel and diesel vehicle drivers about this alternative fuel option. By making E85 and biodiesel more readily available and by promoting its use, the coalition expects to reach its goal of
50 stations offering E85 across Colorado by the end of 2007; they expect many stations to offer biodiesel as well. The next step the coalition has taken is to increase its focus on biodiesel infrastructure. The group plans to increase activity in developing infrastructure for biodiesel blends of B20 and above to support alternative fuels. "As we were able to provide some funding for E85 infrastructure, it freed up capital from station owners who could install biodiesel tanks at the same time," Lewis explained. "So in many cases, we were able to support two alternative fuels."

In fewer than two years, the coalition expects to increase the number of E85 fueling stations from 10 to 50; assist station owners in financing infrastructure; provide local, state, and federal fleets with alternative fuel availability; and educate the public and dealerships on the advantages and availability of E85 and biodiesel. Its success provides a roadmap for other states to follow.

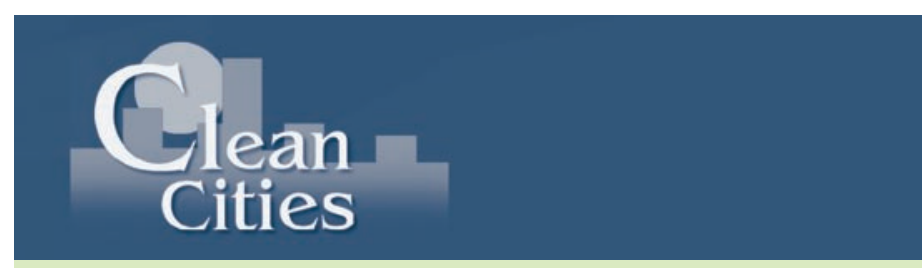

\section{Resources}

DOE's Clean Cities and EPAct activities offer many resources in support of alternative fuels and vehicles.

Alternative Fuels Data Center:

www.eere.energy.gov/afdc

Clean Cities Web site:

www.eere.energy.gov/cleancities

E85 Toolkit:

www.eere.energy.gov/afdcle85toolkit

Clean Cities Fleet Guide - Incentives and Laws:

www.eere.energy.gov/fleetguide/incen_laws.html

\section{For More Coalition Information}

Megan Castle, Public Information Officer

Governor's Energy Office

303-866-2262

www.colorado.gov
Sponsored by the U.S. Department of Energy

Energy Efficiency and Renewable Energy

FreedomCAR and Vehicle Technologies Program

For more information contact: EERE Information Center

1-877-EERE-INF (1-877-337-3463)

www.eere.energy.gov

Prepared by the National Renewable Energy Laboratory (NREL)

NREL is a U.S. Department of Energy National Laboratory

Operated by Midwest Research Institute $\bullet$ Battelle
A Strong Energy Portfolio for a Strong America

Energy efficiency and clean, renewable energy will mean a stronger economy,

a cleaner environment, and greater energy independence for America. Working with a wide array of state, community, industry, and university partners, the U.S. Department of Energy's Office of Energy Efficiency and Renewable Energy invests in a diverse portfolio of energy technologies.

DOE/GO-102007-2439 • June 2007

Printed with a renewable-source ink on paper containing at least $50 \%$ wastepaper, including $10 \%$ postconsumer waste. 